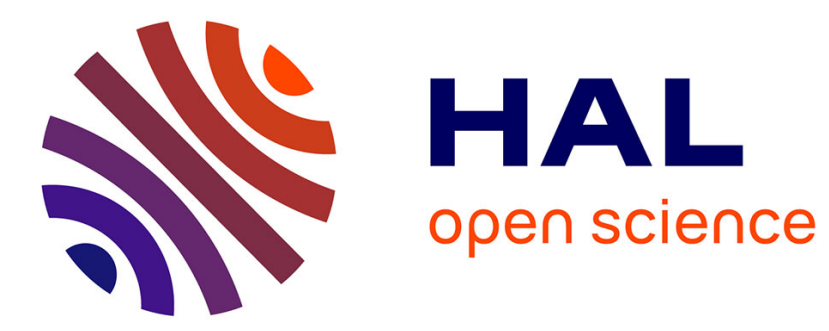

\title{
Ghrelin and reproductive disorders
}

Andrea Repaci, Alessandra Gambineri, Uberto Pagotto, Renato Pasquali

\section{To cite this version:}

Andrea Repaci, Alessandra Gambineri, Uberto Pagotto, Renato Pasquali. Ghrelin and reproductive disorders. Molecular and Cellular Endocrinology, 2011, 10.1016/j.mce.2011.02.022 . hal-00706315

\section{HAL Id: hal-00706315 https://hal.science/hal-00706315}

Submitted on 10 Jun 2012

HAL is a multi-disciplinary open access archive for the deposit and dissemination of scientific research documents, whether they are published or not. The documents may come from teaching and research institutions in France or abroad, or from public or private research centers.
L'archive ouverte pluridisciplinaire HAL, est destinée au dépôt et à la diffusion de documents scientifiques de niveau recherche, publiés ou non, émanant des établissements d'enseignement et de recherche français ou étrangers, des laboratoires publics ou privés. 


\section{Accepted Manuscript}

Title: Ghrelin and reproductive disorders

Authors: Andrea Repaci, Alessandra Gambineri, Uberto

Pagotto, Renato Pasquali

PII: $\quad$ S0303-7207(11)00159-6

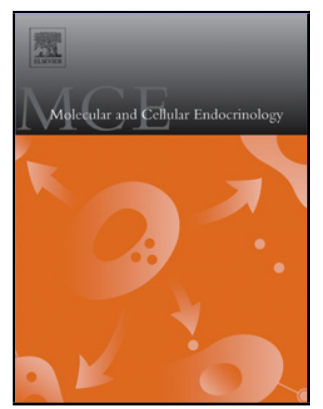

DOI:

doi:10.1016/j.mce.2011.02.022

Reference: $\quad$ MCE 7785

To appear in: $\quad$ Molecular and Cellular Endocrinology

Received date: $\quad 19-1-2011$

Revised date: 26-2-2011

Accepted date: $\quad$ 26-2-2011

Please cite this article as: Repaci, A., Gambineri, A., Pagotto, U., Pasquali, R., Ghrelin and reproductive disorders, Molecular and Cellular Endocrinology (2010), doi:10.1016/j.mce.2011.02.022

This is a PDF file of an unedited manuscript that has been accepted for publication. As a service to our customers we are providing this early version of the manuscript. The manuscript will undergo copyediting, typesetting, and review of the resulting proof before it is published in its final form. Please note that during the production process errors may be discovered which could affect the content, and all legal disclaimers that apply to the journal pertain. 


\section{Ghrelin and reproductive disorders}

Andrea Repaci, Alessandra Gambineri, Uberto Pagotto, and Renato Pasquali

Division of Endocrinology, St. Orsola-Malpighi Hospital, University Alma Mater Studiorum, Bologna, Italy

Word number: 5938 (references excluded); abstract: 142

Address all correspondence and requests for reprints to:

Renato Pasquali, M.D., Division of Endocrinology, Department of Clinical Medicine, St.

Orsola-Malpighi Hospital, University Alma Mater Studiorum, Via Massarenti 9, 40138

Bologna, Italy.

Phone: +39516364147; fax +39516363080

E-mail: renato.pasquali@unibo.it.

Disclosure Summary: The authors have nothing to disclose. 


\section{Abbreviations}

Cyclic Adenosine Monophosphate $=\mathrm{cAMP}$

Body mass index $=\mathrm{BMI}$

des-Gln14-ghrelin or des-acyl-ghrelin = des-ghrelin

Follicle Stimulating Hormone $=$ FSH

Free Fatty Acid = FFA

Gonadotropin Releasing Hormone $=\mathrm{GnRH}$

Growth Hormone Secretagogue Receptor type 1a = GHSR-1a

Growth Hormone $=\mathrm{GH}$

Hypothalamic-Pituitary-Gonadal axis = HPG axis

Luteinizing Hormone $=\mathrm{LH}$

Neuropeptide Y = NPY

Polycystic Ovary Syndrome $=$ PCOS

Prolactin $=\mathrm{PRL}$ 


\begin{abstract}
Ghrelin is an important factor involved in most of the metabolic and hormonal signals which adapt the reproductive functions in conditions of altered energy balance. Moreover, the coordinated role of leptin and ghrelin appears in fact to have a specific role in the regulation of puberty. Systemic action of ghrelin on the reproductive axis involves the control of the hypothalamic-pituitary-gondal axis. In addition, it has been shown that ghrelin may directly act at a gonadal level in both females and males. Available data also demonstrate that sex steroid hormones and gonadotropins may in turn regulate the gonadal effect of ghrelin, as documented by studies performed in females with the polycystic ovary syndrome and in hypogonadal men. Notably, recent studies also confirm a potentially important role for ghrelin in fetal and neonatal energy balance, and specifically in allowing fetal adaptation to an adverse intrauterine environment.
\end{abstract}




\section{Introduction}

The discovery of ghrelin was identified by reverse pharmacology in late 1999 (Kojima et al., 1999) after the identification of its receptor GHSR-1a (Howard et al., 1996). Ghrelin is primarily synthesized as a pre-prohormone consisting of 117 amino acids. Cleavage of preproghrelin results in different forms of ghrelin, a 28 amino acid form (with C-terminal Arg) or a 27 amino acid form (with C-terminal Pro) generated byalternative splicing of the gene product. Ghrelin that is active at the GHSR-1a receptor is octanoylated on serine 3 (Kojima et al., 1999). Des-ghrelin, is a non-octanoylated form and does not bind to or activate the GHSR-1a (Hosoda et al., 2003). Ghrelin is highly conserved across several species and widely expressed in different tissues indicating its physiological importance (Smith et al., 1999; Van Der Lely et al., 2004). The majority of circulating ghrelin is synthesized and secreted by X/A-like cells localized within the oxyntic glands of the mucosa of the gastric fundus (Sakata et al., 2002). Other sources of ghrelin are small intestine, pancreas, lymphocytes, placenta, kidney, lung, pituitary, brain and the gonads (Ueberberg et al. 2009), which directly implies that ghrelin may be involved in many functions of the organism. In essence, ghrelin has been found to have the following functions: (i) increased GH secretion without any efficacy on its synthesis (Date et al., 2000; Takaya et al. 2000), (ii) stimulation of food intake and regulation of energy (Castañeda et al., 2010; Cowley et al. 2003), (iii) stimulation of secretion of PRL and ACTH (Pecori Giraldi et al., 2007; Schmid et al., 2005; Stevanović et al. 2007;), (iv) regulation of the secretion of insulin and blood glucose levels (Gauna et al., 2004; Gauna et al., 2005), (v) increased learning, memory and modulation of synaptic plasticity (Diano et al., 2006; Pinto et al., 2004), (vi) increased cardiac output in healthy humans and improvement of the cardiac performance in patients with chronic heart failure (Nagaya et al., 2001a; Nagaya et al., 2001b); (vii) inhibition of cardiomyocyte and endothelial cell apoptosis, which suggests cardiovascular 
protection (Baldanzi et al., 2002), (vii) activation of adipogenesis and inhibition of lipolysis in adipocytes (Filigheddu et al., 2007; Muccioli et al. 2004), (ix) influence on bone metabolism (Nikolopoulos et al., 2010) and, finally (x) regulation of reproductive functions (Tena-Sempere 2008), pregnancy and lactation (Fuglsang 2008).

In this review we analyze the impact of ghrelin in reproduction and its relationship with energy balance and sex steroids (summarized in Figure 1).

\section{Ghrelin: another link between energy balance and reproductive system}

The reproductive capacity, defined by the ability to generate fertilizable gametes and to sustain pregnancy and lactation, critically depends on a concerted series of developmental events and the coordinated function of different endocrine elements which compose the HPG axis. The energy balance is defined like a perfect equilibrium between energetic entry and expense. The ability to maintain an equilibrium of the energy balance and the ability to reproduce are essential for survival and maintenance of the species. About 2 million years ago, our ancestors stood up for the first time, and probably at that time the uniform layer of subcutaneous fat in primates of both sexes became differentiated to eventually produce the specific human and sexual characteristics seen today (Federman 2006). Fat in women developed in the lower part of the body in relation to the upright posture, the mechanical condition of pregnancy and the need to have reserves for the newborn. Being probably less useful, body fat in man tended to be significantly reduced and predominantly deposited in the upper body, where it was less likely to hinder mobility and the aptitude for wrestling. It is thus possible that natural selection probably increased this differentiation (Federman 2006). In the prehistoric age, fertility was symbolized as a woman with large hips and breasts and the underlying fat energy stores were essential for reproduction (Federman 
2006). A list of experimental and epidemiological studies conducted in the 1960s-1970s led to the formulation of the so-called critical (fat) mass hypothesis, which defined the need for a certain degree of adiposity (i.e. energy stores) in order to proceed to puberty and to maintain a proper reproductive function in adulthood (Frisch et al., 1970; Frisch et al., 1974). On the other hand, the link between energy balance and stores and reproductive functions, specifically the neuroendocrine and molecular bases responsible for this association, remained largely unknown. In the nineties, the cloning of leptin paved the way for the deciphering of signals and mechanisms responsible for the endocrine control of food intake and energy balance (Ahima et al., 2000, Casanueva and Dieguez, 1999; Zhang et al., 1994). We now know that leptin is not only a molecular signal of adiposity, but also plays a pivotal role in the development of puberty and in the subsequent regulation of reproductive functions (Chan et al., 2006). Interestingly, the mechanisms whereby leptin regulates fertility are multifaceted and likely involve actions at different levels of the HPG axis (TenaSempere and Barreiro, 2002a). The hypothalamic areas, the key site for the central control of food intake and neuroendocrine function, are also the primary target for the reproductive actions of leptin, where the peptide stimulating kiss-neurons favor activation of GnRH (Smith et al., 2006). Ghrelin has been hypothesized to functionally antagonize the effects of leptin on energy balance and, therefore, in the regulation of fat stores and body weight. In fact, shortly after its discovery, it was reported that ghrelin may promote food intake and weight gain and fat mass in experimental animals, independently of GH secretion (Nakazato et al., 2001; Strassburg et al., 2008; Tschop et al., 2000; Wortley et al., 2005). Unlike leptin, which increases with increasing BMI and adiposity (Woods and D'Alessio, 2008), ghrelin tends in fact to be inversely correlated with BMI, in both children and adults (Reinehr et al., 2007; Tschop et al., 2001a; Vicennati et al., 2007). It has been suggested that the decreased levels of ghrelin in obesity may reflect a compensatory adaptation aimed at reducing food 
intake (particularly hunger) (Tschop et al.2001a). The active role of ghrelin in the control of food intake is further emphasized by the findings that patients with the Prader-Willi syndrome are hyperphagic and have higher than normal circulating ghrelin levels (DelParigi et al. 2002), whereas in conditions of negative energy balance such as cachexia or anorexia high levels of ghrelin likely represent an effect to compensate for body wasting (Nagaya et al., 2001c; Otto et al., 2001; Shimizu et al., 2003; Tacke et al. 2003; Yoshimoto et al., 2002). Accordingly, numerous studies have shown that ghrelin increases in obese individuals following dietary induced weight loss (Cummings et al., 2002; Hansen et al., 2002).

Ghrelin is secreted principally from the gastric mucosa in starving conditions or before the meal and decreases post-prandially, suggesting a link between the ultradian ghrelin secretion profile and individual ingestive behavior (Bellone et al., 2002; Cummings et al., 2001; Tschop et al., 2001b). In addition, ghrelin has been found to be related to a "meal pattern learning" independent of the nutrient status (Drazen et al. 2006). In fact ghrelin has been described to be relevant for food seeking behavior and meal initiation (Cummings et al., 2004; Cummings 2006). Very recent clinical studies utilizing magnetic resonance imaging have shown that ghrelin administration increases the neural response to pictures of food in the amygdala, orbitofrontal cortex, anterior insula, and striatum, which implies a role for ghrelin in hedonic and incentive responses to food-related cues (Malik et al. 2008). Macronutrient composition may represent one regulatory factor, with all macronutrients being able to suppress ghrelin secretion, albeit to a different extent. Among other modulators, insulin is believed to have a negative impact on ghrelin secretion (Cappiello et al., 2002; Eden Engstrom et al., 2003; Fick et al., 2009; Hoybye et al., 2003; Kempa et al., 2007; Kokkinos et al., 2007; Lucidi et al., 2002; Murdolo et al., 2003; Norrelund et al., 2002; QI et al., 2003; Saad et al., 2002; Schaller et al., 2003; Toshinai et al., 2001). 
How and to what extent circulating ghrelin binds its receptors in the brain remains partially unclear, and it has been suggested that this may occur via circumventricular organs such as the median eminence, or directly in the arcuate nucleus. Ghrelin may in fact cross the bloodbrain barrier via active transport or passive diffusion (Banks et al., 2002; Banks et al., 2008). In the dorsomedial hypothalamus, a region involved in the regulation of food intake (Halem et al., 2004), both ghrelin and BIM-28163 (a receptor antagonist) may regulate neurons involved in the modulation of ghrelin action on weight gain (Bluet-Pajot et al., 1998; Halem et al. 2005), by still undefined receptors (Sun et al., 2004).

Ghrelin seems to activate at least two signal transduction pathways that regulate calcium, which in turn may differentially regulate food intake, $\mathrm{GH}$ secretion and vascular inflammation. These signals may include calcium release by the adenylate cyclase-protein kinase A (AC-PKA) pathway in NPY expressing cells of the rat arcuate nucleus (Kohno et al., 2003) and GH release through the phospholipase C protein kinase C PLC-PKC pathway (Chen et al., 1996), and may reflect two distinct components of ghrelin receptor signaling (Cassoni et al., 2001). Additionally, it has been shown that ghrelin increases food intake in relation to fasting through the activation of AMP-activated protein kinase (AMPK) and acetyl CoA carboxylase (ACC) and the inhibition of fatty acid synthase (FAS) in the ventral medial hypothalamus (Lopez et al. 2008), an effect which appears to be mediated by increased mitochondrial uncoupling protein2 (UCP2) expression (Andrews et al., 2008). Moreover, ghrelin and its receptor GSHR-1a are abundantly expressed in the arcuate nucleus of the hypothalamus, and particularly in neurons coexpressing the orexigenic peptides NPY and agouti related peptide (AGRP) (Kamegai et al. 2001; Nakazato et al., 2001), therefore favouring weight gain (Andrews et al. 2008; Lopez et al. 2008). The adipogenic actions of ghrelin have also been suggested to be mediated directly by the regulation of peroxisome proliferator activated receptor $\gamma(\mathrm{PPAR}-\gamma)$ activity (Barazzoni et 
al., 2005; Choi et al., 2003; Thompson et al., 2004), although it has been suggested that ghrelin may also indirectly regulate peripheral adiposity through the hypothalamic melanocortin receptors and the efferent sympathetic nervous system independent of food intake (Nogueiras et al., 2007; Theander-Carrillo et al., 2006). These observations led to the proposal that ghrelin operates as a peripheral signal for energy insufficiency, whose levels rise in conditions of negative energy balance in order to activate homeostatic responses to keep stable the whole body energy balance (Tang-Christensen et al., 2004; Zigman and Elmquist, 2003).

Considering the prototypic example of leptin (Chan et al., 2006) and the emergent biological profile of ghrelin, it has been hypothesized that ghrelin might contribute, in conjunction with other metabolic signals, to the physiologic coupling of reproduction and energy reserves. This possibility has now been supported by a number of experimental observations, demonstrating biological actions of ghrelin at different levels of the HPG axis and the reproductive system.

\section{Systemic action of ghrelin on the reproductive axis}

Control of the hypothalamic-pituitary-gonadal axis: animal studies

The effects of ghrelin upon gonadotropins and PRL secretion have been explored in a limited number of models and animal species, including rats, primates and sheep (Fernández-Fernández et al., 2004; Fernández-Fernández et al., 2005a; Furuta et al., 2001; Harrison et al., 2008; Iqbal et al., 2006; Kluge et al., 2007; Lanfranco et al., 2008; Vulliémoz et al., 2004). These studies showed that central administration of ghrelin suppressed pulsatile LH secretion in ovariectomized female rats (Furuta et al., 2001). Subsequently it was shown that intracerebroventricular administration of ghrelin (3 
$\mathrm{nmol} / \mathrm{rat}$ ) evoked a significant inhibition of LH secretion in cyclic female rats throughout the estrous cycle, as well as in ovariectomized females (Fernández-Fernández et al., 2006). Likewise, GnRH secretion by hypothalamic fragments from ovariectomized females has been found to be significantly inhibited by ghrelin (Fernández-Fernández et al., 2006). In contrast, other studies have shown that ghrelin stimulated, in a dose-dependent way, basal LH and FSH secretion by pituitary tissue in vitro, which was dependent on the phase of the estrous cycle, as it was neither detected at estrus nor observed after ovariectomy (FernándezFernández et al., 2006). Conversely, GnRH-stimulated LH secretion in vitro was persistently inhibited by ghrelin regardless of the stage of the cycle, whereas stimulated FSH secretion was only inhibited by ghrelin at estrus (Fernández-Fernández et al., 2006). Overall these data illustrate a complex mode of action of ghrelin upon the HPG axis, with predominant inhibitory effects at central (hypothalamic) levels and upon GnRH-induced gonadotropin secretion, and a direct stimulatory action on basal LH and FSH secretion. Interestingly, the inhibitory effects of ghrelin on LH secretion are mimicked by the unacylated form of the molecule (des-ghrelin) in different experimental paradigms (Martini et al., 2006), suggesting acontribution of mechanisms independent of the classical GHSR-1a. In addition, it has been demonstrated that ghrelin decreases $\mathrm{GnRH}$ release by hypothalamic explants ex vivo (Fernández-Fernández et al., 2005a), reinforcing the contention of a major central (hypothalamic) site of action for its inhibitory effects on the pituitary axis. This agrees with the proposed role of ghrelin as a signal of energy insufficiency which frequently occurs together with suppressed gonadotropin levels (Fernández-Fernández et al., 2006).

Control of the hypothalamic-pituitary axes: human studies

Studies in humans are very sparse and all have shown that ghrelin infusion partially inhibited spontaneous pulsatile secretion of LH. (Kluge et al., 2007; Lanfranco et al., 2008; Lanfranco et al., 2010). 
Ghrelin, testis and ovaries: animal studies.

The possibility that ghrelin may directly act at the gonadal level was conceivable with the documented effects of other peripheral regulators of energy balance such as leptin, particularly on the male gonads (Tena-Sempere and Barreiro, 2002a). Tanaka et al. (2001) identified a testis-specific ghrelin gene derived transcript in the mouse. This shows that ghrelin gene expression is ubiquitous and in this case this alternatively spliced variant could play a role in local control of spermatogenesis and in the synthesis of testosterone. Others detected ghrelin in rat Leydig cells at advanced stages of maturation, regardless of their fetal or adult origin (Barreiro et al., 2002). Moreover, further data supported the concept that ghrelin expression in the testis is not apparently modulated by FSH, GH, iodothyronines or glucocorticoids; conversely it appears to be under the specific control of pituitary LH (Barreiro et al., 2002), which is in good agreement with the fact that testicular LH receptors are solely expressed in Leydig cells (Huhtaniemi 2003). Subsequently, expression of the putative ghrelin receptor was demonstrated by a combination of semiquantitative reverse transcription polymerase chain reaction (RT-PCR) and in situ hibrization in rat testis (Barreiro et al., 2003; Tena-Sempere et al. 2002b) and that the expression of the GHSR-1a receptor increases after puberty and reaches peak values in adulthood (Barreiro et al., 2003). This suggests that during pubertal development a shift in the pattern of splicing of the GHSR gene takes place in rat testis, thereby favoring the expression of the biologically active GSHR-1a, which might imply considerable changes in net ghrelin sensitivity with sexual maturation. Location analyses in the rat testis also revealed a scattered pattern of distribution of GHSR-1a, with specific expression in somatic Sertoli and Leydig cells, and eventually in germ cells (Barreiro et al., 2003). As for leptin, testicular expression of the GHSR gene appeared under hormonal regulation, specifically by pituitary FSH, other than by ghrelin itself. Thus, not only ghrelin expression, but also testicular sensitivity to ghrelin 
is likely regulated by hormonal (homologous and heterologous) signals, which is highly suggestive of a finely tuned, direct action of ghrelin in the control of testicular function. In the testis ghrelin was proven to significantly inhibit in a dose-dependent manner both LH- or human Chorionic Gonadotropin (hCG)-stimulated testosterone secretion, by reducing cAMP formation and reducing levels of mRNAs encoding several key factors in the steroidogenic pathway (Tena-Sempere et al., 2002b). The fact that ghrelin may reduce LH-stimulated testosterone secretion seems to contradict the idea that $\mathrm{LH}$ by itself is a regulator of testicular ghrelin expression, so it is likely that ghrelin operates as a local regulator in the fine-tuning of the steroidogenic actions of $\mathrm{LH}$, thereby participating in the autolimitation of the testicular testosterone response to gonadotropic stimulation (Barreiro et al., 2002). Alternatively, such an inhibitory effect upon testosterone secretion could reflect the activity of the systemic, gut-derived ghrelin, whose circulating levels are inversely correlated with BMI (Huhtaniemi 2003). Therefore, it is conceivable that elevated ghrelin levels (like those observed in energy insufficiency) might contribute to the suppression of male reproductive axis in situations of negative energy balance.

In addition to its steroidogenic effects, ghrelin might also directly regulate seminiferous tubule functions because the expression of GHSR-1a has been demonstrated in the tubular compartment of the testis (Barreiro et al., 2003). In fact, it has been shown that ghrelin is able to inhibit the expression of the gene encoding stem cell factor, both after intra-testicular injection in vivo as well as following challenge of staged seminiferous tubule fragments in culture (Barreiro et al., 2004). Notably, stem cell factor is a Sertoli cell product that has been identified as the major paracrine stimulator of germ cell development, acting as a survival factor for spermatogonia, spermatocytes and spermatids in the adult rat seminiferous epithelium (Hakovirta et al., 1999; Yan et al. 2000a). In addition, testicular stem cell factor has also been involved in Leydig cell development and survival (Yan et al. 2000b). Thus, 
the actions of ghrelin upon tubular stem cell factor mRNA expression might have implications not only in the control of spermatogenesis but also upon Leydig cell proliferation. This is in agreement with the finding that ghrelin is able to inhibit the proliferative rate of immature Leydig cells both during puberty development and after selective ablation of pre-existing mature Leydig cells by administration of ethylene dimethane sulfonate (EDS) (Barreiro et al., 2004).

Testis derives from the under-differentiated gonad, so expression of ghrelin and its receptor in adult ovary is probable. Caminos et al. (2003) found for the first time that ghrelin mRNA levels significantly varied depending on the phase of the cycle, with the lowest expression levels in proestrus and maximum values in the diestrous (day 1) phase. Such a cyclic profile of expression, with peak levels in the luteal stages, is highly suggestive of predominant expression of ghrelin in the corpora lutea of the current cycle. Thus, ghrelin mRNA levels reached their highest value when the corpora lutea entered into the functional phase and remained lower during corpora luteal formation and regression. This contention was further substantiated by immunohistochemical analyses, which showed intense and specific ghrelin immunoreactivity in the cytoplasm of steroidogenic luteal cells (Caminos et al., 2003). The profile of ghrelin expression in the corpora lutea was roughly coincidental with its peak in functional activity and paralleled the pattern of progesterone secretion (Caminos et al., 2003; Duggal et al., 2002), which is suggestive of a potential functional role of ghrelin in the regulation of luteal development and/or function in the rat. Treatment with GnRH antagonists, which block the preovulatory surge of gonadotropin and subsequent ovulation, has been shown to be associated with lower levels of ghrelin, and further studies have shown that in the proestrous stage, levels of ghrelin depend on formation of corpora lutea (Caminos et al., 2003; Nekola et al., 1985). The expression of ghrelin and/or GHSR-1a has been reported in the gonads of several mammalian (Zhang et al., 2008) and nonmammalian 
species (Manning et al., 2008; Sirotkin et al., 2006)

Ghrelin, testis and ovaries: human studies.

Initial screening analyses of ghrelin mRNA expression in human tissues provided evidence of expression of the ghrelin gene in the testis (Gaytan et al., 2004; Gnanapavan et al., 2002). Similar to the rat ghrelin peptide, expression of this peptide has been shown in interstitial mature human Leydig cells (Gaytan et al., 2004) and, to a lower extent, in the Sertoli cells (Barreiro et al., 2003). Accordingly, further studies have shown that GHS-R1a is present not only in the mature somatic Sertoli and Leydig cells but also in the germ cells, mainly in the pachytene spermatocytes (Gaytan et al., 2004).

The GHSR-1a has also been detected in human ovaries, particularly in the hilus interstitial cells and in mature corpora lutea and follicular cells, and throughout the ovarian surface epithelium (Gaytan et al., 2003). Additionally, the same receptor has been shown to be strongly expressed in ciliated cells within the fallopian epithelium and, by contrast, no expression has been found in the endometrium and the endocervix (Gaytan et al., 2005). Recently, the expression of the GHSR-1a and $1 \mathrm{~b}$ isoforms has been demonstrated in human granulosa-luteal cells (Viani et al., 2008), and in an in vitro model, it has been reported that, through this receptor, ghrelin significantly inhibited, in a dose-dependent manner, estradiol and progesterone secretion by granulosa-luteal cells. Intriguingly, it could therefore be suggested that such an effect may contribute to suppression of the reproductive axis at times of food deprivation, when limited resources are allocated to major physiological processes. Hypothetically, such an altered balance between the two GHSR isoforms might, under certain conditions, represent a novel mechanism for the regulation of ghrelin sensitivity in the gonads. 
In addition, progesterone secretion by human luteal cells in vitro is also inhibited by ghrelin (Tropea et al., 2007), suggesting that ghrelin may affect the release of luteolytic and luteotropic factors by human luteal cells, as it decreases the release of luteotropic factors and stimulates the secretion of luteolytic factors, thereby participating in the negative control of human luteal function (Tropea et al., 2007).

\section{Ghrelin, pregnancy and placental physiology}

Recent studies have shown that ghrelin may be involved in embryo preimplantantion and development. Both ghrelin and GHSR mRNAs have been detected in the morula and in more advanced stages of embryo development (Kawamura et al., 2003). In addition, ghrelin protein is produced and secreted by the reproductive tract into uterine fluid (Kawamura et al., 2003) where its expression increases during fasting, as occurs in plasma (Gualillo et al., 2002). Ghrelin also negatively regulates cell viability and proliferation (Cassoni et al., 2000; Cassoni et al. 2001; Ghe et al., 2002). Taken together, these findings suggest that during fasting ghrelin may act as a peripheral factor, pre-empting the increased metabolic demand induced by pregnancy and lactation, by inhibiting the development of preimplantation mouse embryos through its specific receptor (Kawamura et al., 2003). The involvement of ghrelin in embryo implantation has been demonstrated by its spatial-temporal expression (like that of its receptors) around the time of implantation (Tanaka et al., 2003). While GHSR-1a mRNA is detected in endometrium throughout the normal menstrual cycle (Edwards 1995a; Edwards 1995b), ghrelin expression is observed in the secretory endometrium, particularly in the luminal and glandular epithelial cells. Since specific products secreted by these cells play an important role in embryo implantation (Edwards 1995a; Edwards 1995b), these data point to a potential role for ghrelin as a 
paracrine/autocrine regulator of human endometrial receptivity (Tawadros et al., 2007).

Tanaka et al. (2003) have also documented strong ghrelin expression in human placenta during the first trimester, especially in extravillous trophoblasts on the tips of chorionic villi, whereas at term the hormone levels are undetectable. It has been hypothesized that, because of its pregnancy-related expression and localization in extravillous trophoblasts cells, which are responsible for the invasion of maternal uterus (Malassine and Cronier, 2002), ghrelin may also play some important role during embryo implantation and placental development. Additionally, GHSR-1a mRNA has been found in the decidua, and in vitro studies have shown that ghrelin was able to enhance human endometrial stromal cell decidualization induced by 8-Br-cAMP (Tanaka et al., 2003). These findings support the hypothesis that ghrelin, together with other messengers (including cytokines, interleukins, sex steroids and prostaglandins, which are released by the invading chorionic tissue), may be a chemical mediator (in a paracrine and autocrine manner) of the regulation of endometrial stromal cell differentiation, which is essential for embryo implantation and the maintenance of pregnancy (Brar et al., 1997; Feinman et al., 1986;Pansini et al. 1984). In addition, reduced ghrelin levels have been demonstrated in third trimester maternal plasma (Fuglsang et al., 2005; Makino et al., 2002), in response to the marked change in maternal energy intake, which further suggests that reduced ghrelin levels could not only reflect maternal energy intake, but also prepare the uterus for parturition, since ghrelin possesses a relaxant effect on the uterus (Hehir et al., 2008).

Ghrelin can cross the feto-placental barrier (Nakahara et al., 2006), therefore a role in fetal development has been hypothesized. This has been confirmed by the finding that fetuses from mothers receiving chronic ghrelin treatment had significantly higher birthweight compared to newborns from saline-treated mothers, and that their growth was significantly favored even in conditions of restricted maternal food intake (Nakahara et al., 2006). This is 
consistent with the concept that maternal ghrelin affects fetal development by mechanisms which are relatively independent of increased maternal nutritional state (Nakahara et al., 2006). This effect has been related to the capacity of ghrelin to favor fetal growth through stimulation of cell proliferation (Nakahara et al., 2006). However, the ghrelin amounts in the fetus are not totally of maternal origin, since it can also be produced in the human fetus (Cortelazzi et al., 2003). In fact, increased ghrelin levels have been found in fetuses with intrauterine growth restriction (Cortelazzi et al., 2003), and recent studies have shown that ghrelin levels in cord blood of full-term neonates are negatively correlated with birthweight (Chanoine et al., 2002). The hypothesis that high ghrelin levels in intrauterine growth restriction fetuses may represent a "hunger signal" is further supported by the finding of higher umbilical cord ghrelin plasma concentrations in small for gestational age (SGA) neonates, compared with appropriate for gestational age (AGA) and large for gestational age (LGA) neonates (Farquhar et al., 2003). These data confirm a potential important role for ghrelin in the fetal and neonatal energy balance, and in allowing fetal adaptation to an adverse intrauterine environment (Farquhar et al., 2003).

\section{Ghrelin and puberty}

As shown for leptin, there are arguments supporting a role of ghrelin in the regulation of puberty onset. Puberty is exquisitely sensitive to the state of energy reserves, therefore ghrelin might represent a metabolic signal of energy insufficiency (Zigman and Elmquist, 2003). It has been reported that repeated injections of ghrelin in male rats, at two different dose regimens, during the pubertal transition, significantly decreased serum LH and testosterone levels and partially delayed balano-preputial separation (an external signal of puberty) (Fernandez-Fernandez et al. 2005a; Martini et al., 2006; Zigman and Elmquist, 
2003). This suggests that elevated ghrelin levels (a signal of energy insufficiency) not only inhibit LH secretion but might also delay the normal timing of puberty. Moreover, studies in rats have shown that female puberty is less sensitive than male puberty to the effects of ghrelin. In fact, repeated injections of ghrelin at low doses to peripubertal females did not induce major changes in serum levels of gonadotropin or estradiol nor did they significantly alter the timing of puberty, as estimated by ages of vaginal opening and first estrus (Fernandez-Fernandez et al., 2005b). In contrast, however, a twice daily injection of $1 \mathrm{nmol}$ ghrelin for 10 days was sufficient to delay vaginal opening and ovarian follicular development and ovulation in pubertal female rats. Taken together, these data suggest that while both male and female rats are sensitive to the modulatory (inhibitory) actions of elevated levels of ghrelin on puberty onset, males appear to be more sensitive than females. This is in contrast to what was reported previously for leptin, as females are more sensitive than males to its regulatory (permissive) effects on puberty onset (Fernandez-Fernandez et al., 2006). This inhibitory effect of ghrelin on LH secretion is elicited not only by acylated ghrelin but also des-ghrelin, which is able to inhibit LH secretion in puberty of male rats via a GHSR-1a independent mechanism (Martini et al., 2006).

The mechanisms whereby ghrelin exerts these modulatory actions on puberty onset remain however to be fully characterized. It is possible that ghrelin is able to inhibit hypothalamic GnRH secretion and pulse frequency, as demonstrated in vitro and ex vivo (FernandezFernandez et al. 2005a; Lebrethon et al., 2007). To date it is still unknown whether ghrelin exerts this effect directly on GnRH neurons or through indirect regulatory pathways. Circumstantial evidence, however, suggests an indirect mode of action, as ghrelin effects on LH secretion were inhibited by a non-selective antagonist of corticotrophin releasing hormone (CRH) (Vulliemoz et al. 2008), and ghrelin was able to inhibit the effect of central elicitors of GnRH/gonadotropin release, such as kisspeptin (Martini et al., 2006). Very 
recent evidence suggests that ghrelin is able to suppress Kiss1 gene expression at discrete hypothalamic sites (Forbes et al., 2009), thus providing, at least in part, the neuroendocrine basis for its inhibitory effects on puberty onset and gonadotropin secretion.

In humans the role of ghrelin on puberty regulation has not been directly investigated, although a progressive decline in circulating ghrelin levels as puberty progresses has been reported (Soriano-Guillén et al. 2004). The decrease in plasma ghrelin levels during puberty progression has been interpreted as a permissive signal of HPG axis maturation, because of a favorable metabolic condition.

\section{Ghrelin and the polycystic ovary syndrome}

Polycystic ovarian syndrome (PCOS) is one of the most common causes of female infertility and affects approximately 6-7\% of reproductive-age women (Azziz et al., 2004). In its classic form, it is characterized by the coexistence of hyperandrogenism, chronic anovulation, and polycystic ovarian morphology. Insulin resistance is very common in women with PCOS, particularly in the presence of obesity, and there is strong evidence this metabolic disorder, often associated with compensatory hyperinsulinemia, may play a triggering role in the pathophysiology of ovarian and adrenal hyperandrogenism, through different mechanisms described in detail elsewhere (Ehrmann 2005). Hyperandrogenism, in turn, may contribute to the generation of insulin resistance through the stimulation of lipolysis, and therefore the increased blood availability of FFA, and specific changes in muscle morphology, by increasing less insulin sensitive type 2 muscle fibers and decreasing the density of capillaries and glycogen content (Cortón et al., 2007). In addition, androgen excess may favor the enlargement of the visceral adipose tissue, which directly worsens insulin sensitivity. 
As reported above, it is well known that ghrelin levels are negatively associated with obesity and positively with the insulin resistance state (Cortón et al., 2007; Shiiya et al., 2002). Several studies have shown that ghrelin levels in obese PCOS were lower than in weightmatched control subjects without PCOS, and an inverse correlation between androgen (particularly androstenedione) blood levels has been found (Barber et al., 2008; Bideci et al., 2008; Glintborg et al., 2006; Moran et al., 2004; Pagotto et al. 2002; Panidis et al., 2005; Panidis et al., 2010; Sağsöz et al., 2009; Schöfl et al., 2002; Zwirska-Korczala et al., 2008), although some studies could not confirm these findings (Orio et al., 2003; Wasko et al., 2004). In one study, an inverse correlation has been reported between the hirsutism score and ghrelin concentrations (Panidis et al., 2010). Interestingly, other studies reported that treatment with flutamide, a pure antiandrogen compound, or with oral contraceptives containing ethinylestradiol plus drospirenone, were able to increase ghrelin levels (Gambineri et al., 2003; Sağsöz et al., 2009). Overall, these data support the concept that androgens are modulators of ghrelin concentration, independent of the presence of obesity. It is however possible that reduced levels of ghrelin in PCOS may depend on a coordinate effect of androgen excess and hyperinsulinemia. It could be speculated that lowered ghrelin in PCOS could act at hypothalamic and pituitary levels promoting LH hypersecretion, favoring in turn increased ovarian androgen production also facilitated by the loss of the inhibitory effect on steroidogenesis.

Ghrelin expression has been demonstrated in the ovaries of women with PCOS (Komarowska et al., 2006), therefore the possibility that androgens may play an autocrine role in favoring increased ovarian steroidogenesis cannot be excluded. Although the available data are still sparse, the paradigm of PCOS suggests a potential capacity of sex hormones in the modulation of the ghrelin system. The effects of sex hormones on gastric secretion of ghrelin is controversial. In one study, ovariectomy or orchiectomy in female and 
male adult rats, respectively, did not affect gastric ghrelin mRNA expression (Gualillo et al., 2001). By contrast, others found that estradiol produced locally in the stomach was able to stimulate ghrelin gene expression even after gonadectomy (Sakata et al., 2006). Another study reported suppressive effects of ovarian estradiol on stomach ghrelin gene expression as well as on the plasma ghrelin concentration (Matsubara et al., 2004). An additional recent study found that estradiol supplementation was followed by increased synthesis and/or acylation of the ghrelin peptide without any effect on its metabolic clearance rate in premenopausal women (Paulo et al., 2008), although another study did not confirm these data (Dafopoulos et al., 2010). Moreover, it has been reported that estrogen administration to a culture system of rat gastric tissue explants, induced a significant decrease in ghrelin secretion, but did not affect either mRNA or protein levels, and that testosterone treatment in orchidectomized rats did not affect gastric ghrelin secretion (Al-Massadi et al., 2010). These conflicting data suggest that sex steroids may affect the ghrelin system not only in the stomach (where estrogen receptors have been described at the level of ghrelin producing cells) (Campbell-Thompson et al., 2001; Matsubara et al., 2004) but also at the peripheral level, however the precise mechanisms still remain largely unknown.

\section{Ghrelin in the hypogonadic men}

The secretion and the regulation of several hormones is sexually dimorphic, and differences between females and males have been demonstrated for leptin (Ostlund et al., 1996). The same seems to be true for ghrelin which, similarly to leptin, tends to be higher in women than in men (Greenman et al., 2009). In men, a significant correlation between ghrelin and testosterone (total or bioavailable) has been reported. In fact, lower ghrelin levels have been shown in hypogonadal men compared with weight-matched eugonadal men or normal 
weight controls (Duran et al., 2008; Naharci et al., 2010; Pagotto et al., 2003), and a negative correlation between ghrelin and insulin resistance has been found (Pagotto et al., 2003). In addition, treatment with testosterone in hypogonadal men tends to restore ghrelin levels to normal (Pagotto et al., 2003). These findings support the concept that androgens may act directly on both peptide expression and synthesis, or indirectly through regulation of FFA metabolism (Broglio et al., 2002), although this latter mechanism is controversial (Mohlig et al., 2002).

Ghrelin may also regulate spermatogenesis, since detectable ghrelin concentrations have been reported in the seminal plasma of men with normospermia and dyspermia. Notably, sperm ghrelin levels are lower than plasma ghrelin levels (Panidis et al., 2008). However, the potential role of ghrelin in the regulation of spermatogenesis and spermatozoa vitality is still largely unknown. Much more research should be performed on this topic, due to the potential impact of ghrelin dysregulation on male infertility.

\section{Conclusions and future directions}

Ghrelin, like leptin, seems to be a key factor linking energy balance and reproductive function in males and females. This important role is supported by the finding of ghrelin and its active receptor in tissues involved in the control of metabolism and in the reproductive system of males and females. Recently, ghrelin has also been found in placenta and in uterus, where it seems to be involved in embryo implantation and pregnancy development, and in decidualization of endometrium. In addition, studies in normal subjects and in hyperandrogenic or hypogonadic disorders demonstrate that ghrelin, sex steroids and gonadotropins strongly influence each other. Although more studies are needed to clarify the complex network between ghrelin and reproduction, these findings have potential clinical implications for the regulation of fertility 


\section{References}

Ahima, R.S., Saper, C.B., Flier, J.S., Elmquist, J.K., 2000. Leptin regulation of neuroendocrine systems. Front. Neuroendocrinol. 21, 263-307.

Al-Massadi, O., Crujeiras, A.B., González, R.C., Pardo, M., Diéguez, C., Casanueva, F.F., Seoane, L.M. 2010. Age, sex, and lactating status regulate ghrelin secretion and GOAT mRNA levels from isolated rat stomach. Am. J. Physiol. Endocrinol. Metab. 299, E341-350

Andrews, Z.B., Liu, Z.W., Walllingford, N., Erion, D.M., Borok, E., Friedman, J.M., Tschöp, M.H., Shanabrough, M., Cline, G., Shulman, G.I., Coppola, A., Gao, X.B., Horvath, T.L., Diano, S., 2008. UCP2 mediates ghrelin's action on NPY/AgRP neurons by lowering free radicals. Nature. 454 (7206), 846-851.

Azziz, R., Woods, K.S., Reyna, R., Key, T.J., Knochenhauer, E.S., Yildiz, B.O. 2004. The prevalence and features of the polycystic ovary syndrome in an unselected population. J. Clin. Endocrinol. Metab. 89, 2745-2749

Baldanzi, G., Filigheddu, N., Cutrupi, S., Catapano, F., Bonissoni, S., Fubini, A., Malan, D., Baj, G., Granata, R., Broglio, F., Papotti, M., Surico, N., Bussolino, F., Isgaard, J., Deghenghi, R., Sinigaglia, F., Prat, M., Muccioli, G., Ghigo, E., Graziani, A., 2002. Ghrelin and des-acyl ghrelin inhibit cell death in cardiomyocytes and endothelial cells through ERK1/2 and PI 3kinase/AKT, J. Cell. Biol. 159, 1029-1037.

Banks, W.A., Tschop, M., Robinson, S.M., Heiman, M.L., 2002. Extent and direction of ghrelin transport across the blood-brain barrier is determined by its unique primary structure. J. Pharmacol. Exp. Ther. 302, 822-827.

Banks, W.A., Burney, B.O., Robinson, S.M., 2008. Effects of triglycerides, obesity, and starvation on ghrelin transport across the blood-brain barrier. Peptides. 29, 2061-2065.

Barazzoni, R., Bosutti, A., Stebel, M., Cattin, M.R., Roder, E., Visintin, L., Cattin, L., Biolo, G., Zanetti, M., Guarnieri, G., 2005. Ghrelin regulates mitochondrial-lipid metabolism gene expression and tissue fat distribution in liver and skeletal muscle. Am. J. Physiol. Endocrinol. Metab. 288, E228-E235.

Barber, T.M., Casanueva, F.F., Karpe, F., Lage, M., Franks, S., McCarthy, M.I., Wass, J.A. 2008. Ghrelin levels are suppressed and show a blunted response to oral glucose in women with polycystic ovary syndrome. Eur. J. Endocrinol. 158, 511-516

Barreiro, M.L., Gaytán, F., Caminos, J.E., Pinilla, L., Casanueva, F.F., Aguilar, E., Diéguez, C., Tena-Sempere, M., 2002. Cellular location and hormonal regulation of ghrelin expression in rat testis. Biol. Reprod. 67, 1768-1776. 
Barreiro, M.L., Suominen, J.S., Gaytán, F., Pinilla, L., Chopin, L.K., Casanueva, F.F., Diéguez, C., Aguilar, E., Toppari, J., Tena-Sempere, M., 2003. Developmental, stage-specific, and hormonally regulated expression of growth hormone secretagogue receptor messenger RNA in rat testis. Biol. Reprod. 68, 1631-40.

Barreiro, M. L., Gaytan, F., Castellano, J. M., Suominen, J. S., Roa, J., Gaytan, M., Aguilar, E., Dieguez, C., Toppari, J., Tena-Sempere, M., 2004. Ghrelin inhibits the proliferative activity of immature Leydig cells in vivo and regulates stem cell factor messenger ribonucleic acid expression in rat testis. Endocrinology. 145, 4825-4834.

Bellone, S., Rapa, A., Vivenza, D., Castellino, N., Petri, A., Bellone, J., Me, E., Broglio, F., Prodam, F., Ghigo, E., Bona, G., 2002. Circulating ghrelin levels as function of gender, pubertal status and adiposity in childhood. J. Endocrinol. Invest. 25, RC13-RC15.

Bideci, A., Camurdan, M.O., Yeşilkaya, E., Demirel, F., Cinaz, P. 2008. Serum ghrelin, leptin and resistin levels in adolescent girls with polycystic ovary syndrome. J. Obstet. Gynaecol. Res. 34, 578-584.

Bluet-Pajot, M.T., Epelbaum, J., Gourdji, D., Hammond, C., Kordon, C., 1998. Hypothalamic and hypophyseal regulation of growth hormone secretion. Cell. Mol. Neurobiol. 18, 101-123.

Brar, A,K., Frank, G.R., Kessler, C.A., Cedars, M.I., Handwerger, S. 1997. Progesteronedependent decidualization of the human endometrium is mediated by cAMP. Endocrine 6, 301307.

Broglio, F., Benso, A., Gottero, C., Prodam, F., Grottoli, S., Tassone, F., Maccario, M., Casanueva, F.F., Dieguez, C., Deghenghi, R., Ghigo, E., Arvat, E. 2002. Effects of glucose, free fatty acids or arginine load on the GH-releasing activity of ghrelin in humans. Clin. Endocrinol. (Oxf) 57, 265-271.

Caminos, J.E., Tena-Sempere, M., Gaytan, F., Sanchez-Criado, J.E., Barreiro, M.L., Nogueiras, R., Casanueva, F.F., Aguilar, E., Dieguez, C., 2003. Expression of ghrelin in the cyclic and pregnant rat ovary. Endocrinology. 144, 1594-1602.

Campbell-Thompson, M., Reyher, K.K., Wilkinson, L.B. 2001. Immunolocalization of estrogen receptor alpha and beta in gastric epithelium and enteric neurons. J. Endocrinol. 171, 65-73.

Cappiello, V., Ronchi, C., Morpurgo, P.S., Epaminonda, P., Arosio, M., Beck-Peccoz, P., Spada, A., 2002. Circulating ghrelin levels in basal conditions and during glucose tolerance test in acromegalic patients. Eur. J. Endocrinol. 147, 189-194.

Casanueva, F.F., Dieguez, C.,1999. Neuroendocrine regulation and actions of leptin. Front. Neuroendocrinol. 20,317-363.

Cassoni, P., Papotti, M., Catapano, F., Ghe, C., Deghenghi, R., Ghigo, E., Muccioli, G., 2000. 
Specific binding sites for synthetic growth hormone secretagogues in non-tumoral and neoplastic human thyroid tissue. J. Endocrinol. 165, 139-146.

Cassoni, P., Papotti, M., Ghe, C., Catapano, F., Sapino, A., Graziani, A., Deghenghi, R., Reissmann, T., Ghigo, E., Muccioli, G., 2001. Identification, characterization, and biological activity of specific receptors for natural (ghrelin) and synthetic growth hormone secretagogues and analogs in human breast carcinomas and cell lines. J. Clin. Endocrinol. Metab. 86, 17381745.

Castañeda, T.R., Tong, J., Datta, R., Culler, M., Tschöp, M.H., 2010. Ghrelin in the regulation of body weight and metabolism. Front. Neuroendocrinol. 31, 44-60.

Chan, J.L., Matarese, G., Shetty, G.K., Raciti, P., Kelesidis, I., Aufiero, D., De Rosa, V., Perna, F., Fontana, S., Mantzoros, C.S., 2006. Differential regulation of metabolic, neuroendocrine, and immune function by leptin in humans. Proc. Natl. Acad. Sci. U S A. 103, 8481-8486.

Chanoine, J.P., Yeung, L.P., Wong, A.C., Birmingham, C.L., 2002. Immunoreactive ghrelin in human cord blood: relation to anthropometry, leptin, and growth hormone. J. Pediatr. Gastroenterol. Nutr. 35, 282-286.

Chen, C., Wu, D., Clarke, I.J., 1996. Signal transduction systems employed by synthetic GHreleasing peptides in somatotrophs. J. Endocrinol. 148, 381-386.

Choi, K., Roh, S.G., Hong, Y.H., Shrestha, Y.B., Hishikawa, D., Chen, C., Kojima, M., Kangawa, K., Sasaki, S., 2003. The role of ghrelin and growth hormone secretagogues receptor on rat adipogenesis. Endocrinology. 144, 754-759.

Cortelazzi, D., Cappiello, V., Morpurgo, P.S., Ronzoni, S., Nobile De Santis, M.S., Cetin, I., Beck-Peccoz, P., Spada, A., 2003. Circulating levels of ghrelin in human fetuses. Eur. J. Endocrinol. 149,111-116.

Cortón, M., Botella-Carretero, J.I., Benguría, A., Villuendas, G., Zaballos, A., San Millán, J.L., Escobar-Morreale, H.F., Peral, B. 2007. Differential gene expression profile in omental adipose tissue in women with polycystic ovary syndrome. J. Clin. Endocrinol. Metab. 92, 328-337

Cowley, M.A., Smith, R.G., Diano, S., Tschop, M., Pronchuk, N., Grove, K.L., Strasburger, C.J., Bidlingmaier, M., Esterman, M., Heiman, M.L., Garcia-Segura, L.M., Nillni, E.A., Mendez, P., Low, M.J., Sotonyi, P., Friedman, J.M., Liu, H., Pinto, S., Colmers, W.F., Cone, R.D., Horvath, T.L., 2003. The distribution and mechanism of action of ghrelin in the CNS demonstrates a novel hypothalamic circuit regulating energy homeostasis. Neuron. 37, 649-461. Cummings, D.E., Purnell, J.Q., Frayo, R.S., Schmidova, K., Wisse, B.E., Weigle, D.S., 2001. A preprandial rise in plasma ghrelin levels suggests a role in meal initiation in humans. Diabetes. $50,1714-1719$. 
Cummings, D.E., Weigle, D.S., Frayo, R.S., Breen, P.A., Ma, M.K., Dellinger, E.P., Purnell, J.Q., 2002. Plasma ghrelin levels after diet-induced weight loss or gastric bypass surgery. N. Engl. J. Med. 346, 1623-1630.

Cummings, D.E., Frayo, R.S., Marmonier, C., Aubert, R., Chapelot, D., 2004. Plasma ghrelin levels and hunger scores in humans initiating meals voluntarily without time- and food-related cues. Am. J. Physiol. Endocrinol. Metab. 287, E297-E304.

Cummings, D.E., 2006. Ghrelin and the short- and long-term regulation of appetite and body weight. Physiol. Behav. 89, 71-84.

Dafopoulos, K., Chalvatzas, N., Kosmas, G., Kallitsaris, A., Pournaras, S., Messinis, I.E. 2010. The effect of estrogens on plasma ghrelin concentrations in women. J. Endocrinol. Invest. 33, 109-112

Date, Y., Murakami, N., Kojima, M., Kuroiwa, T., Matsukura, S., Kangawa, K., Nakazato, M., 2000. Central effects of a novel acylated peptide, ghrelin, on growth hormone release in rats. Biochem. Biophys. Res. Commun. 275, 477-480.

Del Parigi, A., Tschop, M., Heiman, M.L., Salbe, A.D., Vozarova, B., Sell, S.M., Bunt, J.C., Tataranni, P.A., 2002. High circulating ghrelin: a potential cause for hyperphagia and obesity in prader-willi syndrome. J. Clin. Endocrinol. Metab. 87, 5461-5464.

Diano, S., Farr, S.A., Benoit, S.C., McNay, E.C., Da Silva, I., Horvath, B., Gaskin, F.S., Nonaka, N., Jaeger, L.B., Banks, W.A., Morley, J.E., Pinto, S., Sherwin, R.S., Xu, L., Yamada, K.A., Sleeman, M.W., Tschöp, M.H., Horvath, T.L., 2006. Ghrelin controls hippocampal spine synapse density and memory performance. Nat. Neurosci. 9, 381-388.

Drazen, D.L., Vahl, T.P., D’Alessio, D.A., Seeley, R.J., Woods, S.C., 2006. Effects of a fixed meal pattern on ghrelin secretion: evidence for a learned response independent of nutrient status. Endocrinology. 147, 23-30.

Duggal, P.S., Weitsman, S.R., Magoffin, D.A., Norman, R.J., 2002. Expression of the long (Ob$\mathrm{RB})$ and the short (Ob-RA) forms of leptin receptor throughout the oestrous cycle in the mature rat ovary. Reproduction. 123, 899-905.

Duran, C., Yonem, A., Ustun, I, Ozcan, O., Ipcioglu, O.M., Basekim, C.C. 2008. Plasma ghrelin levels in males with idiopathic hypogonadotropic hypogonadism. Endocrine 34, 81-86.

Eden Engstrom, B., Burman, P., Holdstock, C., Karlsson, F.A., 2003. Effects of growth hormone $(\mathrm{GH})$ on ghrelin, leptin, and adiponectin in GH-deficient patients. J.Clin. Endocrinol. Metab. 88, 5193-5198.

Edwards, R.G. 1995a. Physiological and molecular aspects of human implantation. Hum Reprod 10, 1-13. 
Edwards, R.G. 1995b. Clinical approaches to increasing uterine receptivity during human implantation. Human. Reprod. 10, 60-66.

Ehrmann, D.A., 2005. Polycystic ovary syndrome. N. Engl. J. Med. 352, 1223-1236.

Farquhar, J., Heiman, M., Wong, A.C., Wach, R., Chessex, P., Chanoine, J.P., 2003. Elevated umbilical cord ghrelin concentrations in small for gestational age neonates. J. Clin. Endocrinol. Metab. 88, 4324-4327

Federman, D.D. 2006. The biology of human sex differences. N. Engl. J. Med. 354, 1507-1514

Feinman, M.A., Kliman, H.J., Caltabiano, S., Strauss III J.F. 1986. 8-Bromo- 30,50-adenosine monophosphate stimulates the endocrine activity of human cytotrophoblasts in culture. J. Clin. Endocrinol. Metab. 63, 1211-1217.

Fernández-Fernández, R., Tena-Sempere, M., Aguilar, E., Pinilla, L., 2004. Ghrelin effects on gonadotropin secretion in male and female rats. Neurosci. Lett. 362, 103-107.

Fernandez-Fernandez, R., Tena-Sempere, M., Navarro, V.M., Barreiro, M.L., Castellano, J.M., Aguilar, E., Pinilla, L., 2005a. Effects of ghrelin upon gonadotropin-releasing hormone and gonadotropin secretion in adult female rats: in vivo and in vitro studies. Neuroendocrinology. $82,245-255$.

Fernandez-Fernandez, R., Navarro, V.M., Barreiro, M.L., Vigo, E.M., Tovar, S., Sirotkin, A.V., Casanueva, F.F., Aguilar, E., Dieguez, C., Pinilla, L., Tena-Sempere, M., 2005b. Effects of chronic hyperghrelinemia on puberty onset and pregnancy outcome in the rat. Endocrinology $146,3018-3025$.

Fernandez-Fernandez, R., Martini, A. C., Navarro, V. M., Castellano, J. M., Dieguez, C., Aguilar, E., Pinilla, L., Tena-Sempere, M., 2006. Novel signals for the integration of energy balance and reproduction. Mol. Cell. Endocrinol. 254-255, 127-132.

Fick, L.J., Cai, F., Belsham, D.D., 2009. Hypothalamic preproghrelin gene expression is repressed by insulin via both PI3-K/Akt and ERK1/2 MAPK pathways in immortalized, hypothalamic neurons. Neuroendocrinology. 89, 267-275.

Filigheddu, N., Gnocchi, V.F., Coscia, M., Cappelli, M., Porporato, P.E., Taulli, R., Traini, S., Baldanzi, G., Chianale, F., Cutrupi, S., Arnoletti, E., Ghe, C., Fubini, A., Surico, N., Sinigaglia, F., Ponzetto, C., Muccioli, G., Crepaldi, T.,Graziani, A., 2007. Ghrelin and des-acyl ghrelin promote differentiation and fusion of $\mathrm{C} 2 \mathrm{C} 12$ skeletal muscle cells, Mol. Biol. Cell. 18, 986994.

Forbes, S., Li, X.F., Kinsey-Jones, J., O’Byrne, K., 2009. Effects of ghrelin on Kisspeptin mRNA expression in the hypothalamic medial preoptic area and pulsatile luteinizing hormone secretion in the female rat. Neurosci. Lett. 460, 143-147. 
Frisch, R.E., Revelle, R., 1970. Height and weight at menarche and a hypothesis of critical body weights and adolescent events. Science. 169, 397-399.

Frisch, R.E., McArthur, J.W., 1974. Menstrual cycles: fatness as a determinant of minimum weight for height necessary for their maintenance or onset. Science.185, 949-951.

Fuglsang, J., Skjaerbaek, C., Espelund, U., Frystyk, J., Fisker, S., Flyvbjerg, A., Ovesen, P., 2005. Ghrelin and its relationship to growth hormones during normal pregnancy. Clin. Endocrinol. (Oxf.) 62, 554-599

Fuglsang, J., 2008. Ghrelin in pregnancy and lactation. Vitam. Horm.. 77, 259-284.

Furuta, M., Funabashi, T., Kimura, F., 2001. Intracerebroventricular administration of ghrelin rapidly suppresses pulsatile luteinizing hormone secretion in ovariectomized rats. Biochem. Biophys. Res. Commun. 288, 780-785.

Gambineri, A., Pagotto, U., Tschöp, M., Vicennati, V., Manicardi, E., Carcello, A., Cacciari, M., De Iasio, R., Pasquali, R. 2003. Anti-androgen treatment increases circulating ghrelin levels in obese women with polycystic ovary syndrome. J. Endocrinol. Invest. 26, 629-634.

Gauna, C., Meyler, F.M., Janssen, J.A., Delhanty, P.J., Abribat, T., Van Koetsveld, P., Hofland, L.J., Broglio, F., Ghigo, E., Van der Lely, A.J., 2004. Administration of acylated ghrelin reduces insulin sensitivity, whereas the combination of acylated plus unacylated ghrelin strongly improves insulin sensitivity. J. Clin. Endocrinol. Metab. 89, 5035-5042.

Gauna, C., Delhanty, P.J., Hofland, L.J., Janssen, J.A., Broglio, F., Ross, R.J., Ghigo, E., Van der Lely, A.J., 2005. Ghrelin stimulates whereas des-octanoyl ghrelin inhibits, glucose output by primary hepatocytes. J. Clin. Endocrinol. Metab. 90, 1055-1060.

Gaytan, F., Barreiro, M.L., Chopin, L.K., Herington, A.C., Morales, C., Pinilla, L., Casanueva, F.F., Aguilar, E., Diéguez, C., Tena-Sempere, M., 2003. Immunolocalization of ghrelin and its functional receptor, the type 1a growth hormone secretagogue receptor, in the cyclic human ovary. J. Clin. Endocrinol. Metab. 88, 879-887.

Gaytan, F., Barreiro, M.L., Caminos, J.E., Chopin, L.K., Herington, A.C., Morales, C., Pinilla, L., Paniagua, R., Nistal, M., Casanueva, F.F., Aguilar, E., Diéguez, C., Tena-Sempere, M., 2004. Expression of ghrelin and its functional receptor, the type 1a growth hormone secretagogue receptor, in normal human testis and testicular tumors. J. Clin. Endocrinol. Metab. 89, 400-409.

Gaytan, F., Morales, C., Barreiro, M.L., Jeffery, P., Chopin, L.K., Herington, A.C., Casanueva, F.F., Aguilar, E., Dieguez, C., Tena-Sempere, M., 2005. Expression of growth hormone secretagogue receptor type $1 \mathrm{a}$, the functional ghrelin receptor, in human ovarian surface epithelium, mullerian duct 
derivatives, and ovarian tumors. J. Clin. Endocrinol. Metab. 90, 1798-1804.

Ghe, C., Cassoni, P., Catapano, F., Marrocco, T., Deghenghi, R., Ghigo, E., Muccioli, G., Papotti, M., 2002. The antiproliferative effect of synthetic peptidyl GH secretagogues in human CALU-1 lung carcinoma cells. Endocrinology. 143, 484-491.

Glintborg, D., Andersen, M., Hagen, C., Frystyk, J., Hulstrøm, V., Flyvbjerg, A., Hermann, A.P. 2006. Evaluation of metabolic risk markers in polycystic ovary syndrome (PCOS). Adiponectin, ghrelin, leptin and body composition in hirsute PCOS patients and controls. Eur. J. Endocrinol. 155, 337-345.

nanapavan, S., Kola, B., Bustin, S.A., Morris, D.G., McGee, P., Fairclough, P., Bhattacharya, S., Carpenter, R., Grossman, A.B., Korbonits, M., 2002. The tissue distribution of the mRNA of ghrelin and subtypes of its receptor, GHS-R, in humans. J. Clin. Endocrinol. Metab. 87, 2988.

Greenman, Y., Rouach, V., Limor, R., Gilad, S., Stern, N. 2009. Testosterone is a strong correlate of ghrelin levels in men and postmenopausal women. Neuroendocrinology 89, 79-85.

Gualillo, O., Caminos, J.E., Kojima, M., Kangawa, K., Arvat, E., Ghigo, E., Casanueva, F.F., Diéguez, C. 2001. Gender and gonadal influences on ghrelin mRNA levels in rat stomach. Eur. J. Endocrinol. 144, 687-690.

Gualillo, O., Caminos, J.E., Nogueiras, R., Seoane, L.M., Arvat, E., Ghigo, E., Casanueva, F.F., Diéguez, C., 2002. Effect of food restriction on ghrelin in normal-cycling female rats and in pregnancy. Obes. Res. 10, 682-687.

Hakovirta, H., Yan, W., Kaleva, M., Zhang, F., Vänttinen, K., Morris, P.L., Söder, M., Parvinen, M., Toppari, J., 1999. Function of stem cell factor as a survival factor of spermatogonia and localization of messenger ribonucleic acid in the rat seminiferous epithelium. Endocrinology. 140, 1492-1498.

Halem, H.A., Taylor, J.E., Dong, J.Z., Shen, Y., Datta, R., Abizaid, A., Diano, S., Horvath, T., Zizzari, P., Bluet-Pajot, M.T., Epelbaum, J., Culler, M.D., 2004. Novel analogs of ghrelin: physiological and clinical implications. Eur. J. Endocrinol. 151 (Suppl. 1), S71-S75.

Halem, H.A., Taylor, J.E., Dong, J.Z., Shen, Y., Datta, R., Abizaid, A., Diano, S., Horvath, T.L., Culler, M.D., 2005. A novel growth hormone secretagogue-1a receptor antagonist that blocks ghrelin-induced growth hormone secretion but induces increased body weight gain. Neuroendocrinology. 81, 339-349.

Hansen, T.K., Dall, R., Hosoda, H., Kojima, M., Kangawa, K., Christiansen, J.S., Jørgensen, J.O., 2002. Weight loss increases circulating levels of ghrelin in human obesity. Clin. Endocrinol. (Oxf). 56, 203-206.

Harrison, J.L., Miller, D.W., Findlay, P.A., Adam, C.L., 2008. Photoperiod influences the 
central effects of ghrelin on food intake, GH and LH secretion in sheep. Neuroendocrinology. 87, 182-192.

Hehir, M.P., Glavey, S.V., Morrison, J.J., 2008. Uterorelaxant effect of ghrelin on human myometrial contractility. Am. J. Obstet. Gynecol. 198, 323.e1-5.

Hosoda, H., Kojima, M., Mizushima, T., Shimizu, S., Kangawa, K., 2003. Structural divergence of human ghrelin. Identification of multiple ghrelin-derived molecules produced by posttranslational processing. J. Biol. Chem. 278, 64-70.

Howard, A.D., Feighner, S.D., Cully, D.F., Arena, J.P., Liberator, P.A, Rosenblum, C.I., Hamelin, M., Hreniuk, D.L., Palyha, O.C., Anderson, J., Paress, P.S., Diaz, C., Chou, M., Liu, K.K., McKee, K.K., Pong, S.S., Chaung, L.Y., Elbrecht, A., Dashkevicz, M., Heavens, R., Rigby, M., Sirinathsinghji, D.J., Dean, D.C., Melillo, D.G., Patchett, A.A., Nargund, R., Griffin, P.R., DeMartino, J.A., Gupta, S.K., Schaeffer, J.M., Smith, R.G., Van Der Ploeg, L.H., 1996 . A receptor in pituitary and hypothalamus that functions in growth hormone release. Science. 273, 974-977.

Hoybye, C., Barkeling, B., Espelund, U., Petersson, M., Thoren, M., 2003. Peptides associated with hyperphagia in adults with Prader-Willi syndrome before and during GH treatment, Growth. Horm. IGF. Res. 13, 322-327.

Huhtaniemi, I., 2003. Gonadotrophin actions on the testis genotypes and phenotypes of gonadotrophin and gonadotrophin receptor mutations. Endocr. Dev. 5, 81-103.

Iqbal, J., Kurose, Y., Canny, B., Clarke, I.J., 2006. Effects of central infusion of ghrelin on food intake and plasma levels of growth hormone, luteinizing hormone, prolactin, and cortisol secretion in sheep. Endocrinology. 147, 510-519.

Kamegai, J., Tamura, H., Shimizu, T., Ishii, S., Sugihara, H., Wakabayashi, I., 2001. Chronic central infusion of ghrelin increases hypothalamic neuropeptide Y and Agouti-related protein mRNA levels and body weight in rats. Diabetes. 50, 2438-2443.

Kawamura, K., Sato, N., Fukuda, J., Kodama, H., Kumagai, J., Tanikawa, H., Nakamura, A., Honda, Y., Sato, T., Tanaka, T., 2003. Ghrelin inhibits the development of mouse preimplantation embryos in vitro. Endocrinology. 144, 2623-2633.

Kempa, A., Krzyzanowska-Swiniarska, B., Miazgowski, T., Pilarska, K., 2007. Not insulin but insulin sensitivity, leptin, and cortisol are major factors regulating serum acylated ghrelin level in healthy women. J. Endocrinol. Invest. 30, 659-665.

Kluge, M., Schüssler, P., Uhr, M., Yassouridis, A., Steiger, A., 2007. Ghrelin suppresses secretion of luteinizing hormone in humans. J. Clin. Endocrinol. Metab. 92, 3202-3205.

Kohno, D., Gao, H.Z., Muroya, S., Kikuyama, S., Yada, T., 2003. Ghrelin directly interacts with 
neuropeptide-Y-containing neurons in the rat arcuate nucleus: $\mathrm{Ca} 2+$ signaling via protein kinase A and N-type channel-dependent mechanisms and cross-talk with leptin and orexin. Diabetes. $52,948-956$.

Kojima, M., Hosoda, H., Date, Y., Nakazato, M., Matsuo, H., Kangawa K., 1999. Ghrelin is a growth-hormone-releasing acylated peptide from stomach. Nature. 402, 656-660.

Kokkinos, A., Mourouzis, I., Kyriaki, D., Pantos, C., Katsilambros, N., Cokkinos, D.V., 2007. Possible implications of leptin, adiponectin and ghrelin in the regulation of energy homeostasis by thyroid hormone. Endocrine. 32, 30-32.

Komarowska, H., Waśko, R., Iwanik, K., Majewski, P., Rafińska, L., Warenik-Szymankiewicz, A., Sowiński, J. 2006. Ghrelin ovarian cell expression in patients with polycystic ovary syndrome: an immunohistochemical evaluation. Horm. Metab. Res. 38, 783-788

Lanfranco, F., Bonelli, L., Baldi, M., Me, E., Broglio, F., Ghigo, E., 2008. Acylated ghrelin inhibits spontaneous luteinizing hormone pulsatility and responsiveness to naloxone but not that to gonadotropin-releasing hormone in young men: evidence for a central inhibitory action of ghrelin on the gonadal axis. J. Clin. Endocrinol. Metab. 93, 3633-3639

Lanfranco, F., Motta, G., Baldi, M., Gasco, V., Grottoli, S., Benso, A., Broglio, F., Ghigo, E., 2010. Ghrelin and anterior pituitary function. Front. Horm. Res. 38, 206-211.

Lebrethon, M.C., Aganina, A., Fournier, M., Gerard, A., Parent, A.S., Bourguignon, J.P., 2007. Effects of in vivo and in vitro administration of ghrelin, leptin and neuropeptide mediators on pulsatile gonadotrophin-releasing hormone secretion from male rat hypothalamus before and after puberty. J. Neuroendocrinol. 19, 181-188.

Lopez, M., Lage, R., Saha, A.K., Perez-Tilve, D., Vazquez, M.J., Varela, L., SangiaoAlvarellos, S., Tovar, S., Raghay, K., Rodriguez-Cuenca, S., Deoliveira, R.M., Castaneda, T., Datta, R., Dong, J.Z., Culler, M., Sleeman, M.W., Alvarez, C.V., Gallego, R., Lelliott, C.J., Carling, D., Tschop, M.H., Dieguez, C., Vidal-Puig, A., 2008. Hypothalamic fatty acid metabolism mediates the orexigenic action of ghrelin. Cell. Metab. 7, 389-399.

Lucidi, P., Murdolo, G., Di Loreto, C., De Cicco, A., Parlanti, N., Fanelli, C., Santeusanio, F., Bolli, G.B., De Feo, P., 2002. Ghrelin is not necessary for adequate hormonal counterregulation of insulin-induced hypoglycemia. Diabetes. 51, 2911-2914.

Makino, Y., Hosoda, H., Shibata, K., Makino, I., Kojima, M., Kangawa, K., Kawarabayashi, T., 2002. Alteration of plasma ghrelin levels associated with the blood pressure in pregnancy. Hypertension 39, 781-784.

Malassine, A., Cronier, L. 2002. Hormones and human trophoblast differentiation: a review. Endocrine 19, 3-11. 
Malik, S., McGlone, F., Bedrossian, D., Dagher, A., 2008. Ghrelin modulates brain activity in areas that control appetitive behavior. Cell. Metab. 7, 400-409.

Manning, A.J., Murraym, H.M., Gallant, J.W., Matsuoka, M.P., Radford, E., Douglas, S.E., 2008. Ontogenetic and tissue-specific expression of preproghrelin in the Atlantic halibut, Hippoglossus hippoglossus L. J. Endocrinol. 196, 181-192.

Martini, A.C., Fernandez-Fernandez, R., Tovar, S., Navarro, V.M., Vigo, E., Vazquez, M.J., Davies, J.S., Thompson, N.M., Aguilar, E., Pinilla, L., Wells, T., Dieguez, C., Tena-Sempere, M., 2006. Comparative analysis of the effects of ghrelin and unacylated ghrelin upon luteinizing hormone secretion in male rats. Endocrinology. 147, 2374-2382.

Matsubara, M., Sakata, I., Wada, R., Yamazaki, M., Inoue, K., Sakai, T. 2004. Estrogen modulates ghrelin expression in the female rat stomach. Peptides 25, 289-297.

Mohlig, M., Spranger, J., Otto, B., Ristow. M., Tschöp, M., Pfeiffer, A.F. 2002. Euglycemic hyperinsulinemia, but not lipid infusion, decreases circulating ghrelin levels in humans. J. Endocrinol. Invest. 25, 36-38.

Moran, L.J., Noakes, M., Clifton, P.M., Wittert, G.A., Tomlinson, L., Galletly, C., Luscombe, N.D., Norman, R.J. 2004. Ghrelin and measures of satiety are altered in polycystic ovary syndrome but not differentially affected by diet composition. J. Clin. Endocrinol. Metab. 89, $3337-3344$

Muccioli, G., Pons, N., Ghe`, C., Catapano, F., Granata, R., Ghigo, E., 2004. Ghrelin and desacyl ghrelin both inhibit isoproterenol-induced lipolysis in rat adipocytes via a non-type 1a growth hormone secretagogue receptor. Eur. J. Pharmacol 498, 27-35.

Murdolo, G., Lucidi, P., Di Loreto, C., Parlanti, N., De Cicco, A., Fanelli, C., Perriello, G., Mughetti, D., Pippi, R., Brozzetti, A., Santeusanio, F., De Feo, P., 2003. Circulating ghrelin levels of visceral obese men are not modified by a short-term treatment with very low doses of GH replacement. J. Endocrinol. Invest. 26, 244-249.

Nagaya, N., Kojima, M., Uematsu, M., Yamagishi, M., Hosoda, H., Oya, H., Hayashi, Y., Kangawa, K.., 2001a. Hemodynamic and hormonal effects of human ghrelin in healthy volunteers. Am. J. Physiol. Regul. Integr. Comp. Physiol. 280, R1483-1487.

Nagaya, N., Miyatake, K., Uematsu, M., Oya, H., Shimizu, W., Hosoda, H., Kojima, M., Nakanishi, N., Mori, H., Kangawa, K., 2001b. Hemodynamic, renal, and hormonal effects of ghrelin infusion in patients with chronic heart failure. J. Clin. Endocrinol. Metab. 86, 58545859.

Nagaya, N., Uematsu, M., Kojima, M., Date, Y., Nakazato, M., Okumura, H., Hosoda, H.,.

Shimizu, W., Yamagishi, M., Oya, H., Koh, H., Yutani, C., Kangawa, K., 2001c. Elevated 
circulating level of ghrelin in cachexia associated with chronic heart failure: relationships between ghrelin and anabolic/catabolic factors. Circulation. 104, 2034-2038.

Naharci, M.I., Bolu, E., Karadurmus, N., Basaran, Y. 2010. The relationship between ghrelin levels and insulin resistance in men with idiopathic hypogonadotrophic hypogonadism at diagnosis and after therapy. Endokrynol. Pol. 61, 351-358.

Nakahara, K., Nakagawa, M., Baba, Y., Sato, M., Toshinai, K., Date Y., Nakazato, M., Kojima, M., Miyazato, M., Kaiya, H., Hosoda, H., Kangawa, K., Murakami, N., 2006. Maternal ghrelin plays an important role in rat fetal development during pregnancy. Endocrinology 147, 13331342.

Nakazato, M.., Murakami, N., Date, Y., Kojima, M., Matsuo, H., Kangawa, K., Matsukura, S., 2001. A role for ghrelin in the central regulation of feeding. Nature. 409, 194-198.

Nekola, M.V., Coy, D.H., 1985. Direct and indirect inhibition of ovulation in rats by an antagonist of luteinizing hormone-releasing hormone. Endocrinology. 116, 756-760.

Nikolopoulos, D., Theocharis, S., Kouraklis, G., 2010. Ghrelin, another factor affecting bone metabolism. Med. Sci. Monit. 16, RA147-162.

Nogueiras, R., Wiedmer, P., Perez-Tilve, D., Veyrat-Durebex, C., Keogh, J.M., Sutton, G.M., Pfluger, P.T., Castaneda, T.R., Neschen, S., Hofmann, S.M., Howles, P.N., Morgan, D.A., Benoit, S.C., Szanto, I., Schrott, B., Schurmann, A., Joost, H.G., Hammond, C., Hui, D.Y., Woods, S.C., Rahmouni, K., Butler, A.A., Farooqi, I.S., O’Rahilly, S., Rohner-Jeanrenaud, F., Tschop, M.H., 2007. The central melanocortin system directly controls peripheral lipid metabolism. J. Clin. Invest. 117, 3475-3488.

Norrelund, H., Hansen, T.K., Orskov, H., Hosoda, H., Kojima, M., Kangawa, K., Weeke, J., Moller, N., Christiansen, J.S., Jorgensen, J.O., 2002. Ghrelin immunoreactivity in human plasma is suppressed by somatostatin. Clin. Endocrinol. (Oxf). 57, 539-546.

Orio, F. Jr,, Lucidi, P., Palomba, S., Tauchmanova, L., Cascella, T., Russo, T., Zullo, F., Colao, A., Lombardi, G. and De Feo, P. 2003. Circulating gherlin concentrations in the polycystic ovary syndrome. J. Clin. Endocrinol. Metab. 88, 942-945.

Ostlund, R.E. Jr., Yang, J.W., Klein, S., Gingerich, R. 1996. Relation between plasma leptin concentration and body fat, gender, diet, age, and metabolic covariates. J. Clin. Endocrinol. Metab. 81, 3909-3913.

Otto, B., Cuntz, U., Fruehauf, E., Wawarta, R., Folwaczny, C., Riepl, R.L., Heiman, M.L., Lehnert, P., Fichter, M., Tschop, M., 2001. Weight gain decreases elevated plasma ghrelin concentrations of patients with anorexia nervosa. Eur. J. Endocrinol. 145, 669-673.

Pagotto, U., Gambineri, A., Vicennati, V., Heiman, M.L., Tschöp, M., Pasquali, R. 2002. 
Plasma ghrelin, obesity, and the polycystic ovary syndrome: correlation with insulin resistance and androgen levels. J. Clin. Endocrinol. Metab. 87, 5625-5629.

Pagotto, U., Gambineri, A., Pelusi, C., Genghini, S., Cacciari, M., Otto, B., Castañeda, T., Tschöp, M., Pasquali, R. 2003. Testosterone replacement therapy restores normal ghrelin in hypogonadal men. J. Clin. Endocrinol. Metab. 88, 4139-4143.

Panidis, D., Farmakiotis, D., Koliakos, G., Rousso, D., Kourtis, A., Katsikis, I., Asteriadis, C., Karayannis, V., Diamanti-Kandarakis, E., 2005. Comparative study of plasma ghrelin levels in women with polycystic ovary syndrome, in hyperandrogenic women and in normal controls. Hum. Reprod. 20, 2127-2132.

Panidis, D., Goulis, D.G., Katsikis, I., Koliakos, G., Georgopoulos, N.A., Diamanti-Kandarakis, E. 2008. Serum and seminal plasma ghrelin levels in men with normospermia and dyspermia. Gynecol. Endocrinol. 24, 320-325.

Panidis, D., Asteriadis, C., Georgopoulos, N.A., Katsikis, I., Zournatzi, V., Karkanaki, A., Saltamavros, A.D., Decavalas, G., Diamanti-Kandarakis, E. 2010. Decreased active, total and altered active to total ghrelin ratio in normal weight women with the more severe form of polycystic ovary syndrome. Eur. J. Obstet. Gynecol. Reprod. Biol. 149, 170-174.

Pansini, F., Bergamini, C.M., Bettocchi, Jr. S., Malfaccini, M., Santoiemma, M., Scoppetta, V., Bagni B, Mollica G. 1984. Sex steroid hormones influence the cAMP content in human endometrium during the menstrual cycle. Gynecol. Obstet. Invest. 18, 174-177.

Paulo, R.C., Brundage, R., Cosma, M., Mielke, K.L., Bowers, C.Y., Veldhuis, J.D. 2008. Estrogen elevates the peak overnight production rate of acylated ghrelin. J. Clin. Endocrinol. Metab. 93, 4440-4447

Pecori Giraldi, F., Bucciarelli, L.G., Saccani, A., Scacchi, M., Pesce, S., Losa, M., Cavagnini, F., 2007. Ghrelin stimulates adrenocorticotrophic hormone (ACTH) secretion by human ACTHsecreting pituitary adenomas in vitro. J. Neuroendocrinol.19, 208-212.

Pinto, S., Roseberry, A.G., Liu, H., Diano, S., Shanabrough, M., Cai, X., Friedman, J.M., Horvath, T.L.., 2004. Rapid rewiring of arcuate nucleus feeding circuits by leptin. Science. 304, $110-115$.

Qi, X., Reed, J., Englander, E.W., Chandrashekar, V., Bartke, A., Greeley Jr., G.H., 2003. Evidence that growth hormone exerts a feedback effect on stomach ghrelin production and secretion. Exp. Biol. Med. (Maywood). 228, 1028-1032.

Reinehr, T., De Sousa, G., Roth, C.L., 2007 .Obestatin and ghrelin levels in obese children and adolescents before and after reduction of overweight. Clin. Endocrinol (Oxf). 68, 304-310.

Saad, M.F., Bernaba, B., Hwu, C.M., Jinagouda, S., Fahmi, S., Kogosov, E., Boyadjian, R., 
2002. Insulin regulates plasma ghrelin concentration. J. Clin. Endocrinol. Metab. 87, 39974000.

Sağsöz, N., Orbak, Z., Noyan, V., Yücel, A., Uçar, B., Yildiz, L. 2009. The effects of oral contraceptives including low-dose estrogen and drospirenone on the concentration of leptin and ghrelin in polycystic ovary syndrome. Fertil. Steril. 92, 660-666.

Sakata, I., Nakamura, K., Yamazaki, M., Matsubara, M., Hayashi, Y., Kangawa, K., Sakai, T., 2002. Ghrelin-producing cells exist as two types of cells, closed- and opened-type cells, in the rat gastrointestinal tract. Peptides. 23, 531-536.

Sakata, I., Tanaka, T., Yamazaki, M., Tanizaki, T., Zheng, Z., Sakai, T. 2006. Gastric estrogen directly induces ghrelin expression and production in the rat stomach. J. Endocrinol. 190, 749757.

Schaller, G., Schmidt, A., Pleiner, J., Woloszczuk, W., Wolzt, M., Luger, A., 2003. Plasma ghrelin concentrations are not regulated by glucose or insulin: a doubleblind, placebo-controlled crossover clamp study. Diabetes. 52, 16-20.

Schmid, D.A., Held, K., Ising, M., Uhr, M., Weikel, J.C., Steiger, A., 2005. Ghrelin stimulates appetite, imagination of food, GH, ACTH, and cortisol, but does not affect leptin in normal controls. Neuropsychopharmacology. 30, 1187-1192.

Schöfl, C., Horn, R., Schill, T., Schlösser, H.W., Müller, M.J., Brabant, G. 2002. Circulating ghrelin levels in patients with polycystic ovary syndrome. J. Clin. Endocrinol. Metab. 87, 46074610.

Shiiya, T., Nakazato, M., Mizuta, M., Date, Y., Mondal, M.S., Tanaka, M., Nozoe, S.I., Hosoda, H., Kangawa, K., Matsukura, S., 2002. Plasma ghrelin levels in lean and obese humans and the effect of glucose on ghrelin secretion. J. Clin. Endocrinol. Metab. 87, 240-244.

Shimizu, Y., Nagaya, N., Isobe, T., Imazu, M., Okumura, H., Hosoda, H., Kojima, M., Kangawa, K., Kohno, N., 2003. Increased plasma ghrelin level in lung cancer cachexia. Clin. Cancer. Res. 9, 774-778.

Sirotkin, A.V., Grossmann, R., María-Peon, M.T., Roa, J., Tena-Sempere, M., Klein, S., 2006. Novel expression and functional role of ghrelin in chicken ovary. Mol. Cell. Endocrinol.26, 1525.

Smith, J.T., Popa, S.M., Clifton, D.K., Hoffman, G.E., Steiner, R.A., 2006. Kiss1 neurons in the forebrain as central processors for generating the preovulatory luteinizing hormone surge. J. Neurosci. 26, 6687-6694.

Smith, R.G., Palyha, O.C., Feighner, S.D., Tan, C.P., McKee, K.K., Hreniuk, D.L., Yang, L., 
Morriello, G., Nargund, R., Patchett, A.A., Howard, A.D., 1999. Growth hormone releasing substances: types and their receptors. Horm. Res. 51 (Suppl 3), 1-8

Soriano-Guillén, L., Barrios, V., Chowen, J.A., Sánchez, I., Vila, S., Quero, J., Argente, J. 2004. Ghrelin levels from fetal life through early adulthood: relationship with endocrine and metabolic and anthropometric measures. J. Pediatr., 144, 30-35.

Stevanović, D., Milosević, V., Starcević, V.P., Severs, W.B., 2007. The effect of centrally administered ghrelin on pituitary ACTH cells and circulating ACTH and corticosterone in rats. Life. Sci. 80, 867-872.

Strassburg, S., Anker, S., Castaneda, T., Burget, L., Perez-Tilve, D., Pfluger, P.T., Nogueiras, R., Halem, H., Dong, J.Z., Culler, M., Datta, R., Tschop, M.H., 2008. Long-term effects of ghrelin and ghrelin receptor agonists on energy balance in rats. Am. J. Physiol. Endocrinol. Metab. 295, E78-84.

Sun, Y., Wang, P., Zheng, H., Smith, R.G., 2004. Ghrelin stimulation of growth hormone release and appetite is mediated through the growth hormone secretagogue receptor. Proc. Natl. Acad. Sci. USA. 101, 4679-4684.

Tacke, F., Brabant, G., Kruck, E., Horn, R., Schoffski, P., Hecker, H., Manns, M.P., Trautwein, C., 2003. Ghrelin in chronic liver disease. J. Hepatol. 38, 447-454.

Takaya, K., Ariyasu, H., Kanamoto, N., Iwakura, H., Yoshimoto, A., Harada, M., Mori, K., Komatsu, Y., Usui, T., Shimatsu, A, Ogawa, Y., Hosoda, K., Akamizu, T., Kojima, M., Kangawa, K., Nakao, K., 2000. Ghrelin strongly stimulates growth hormone release in humans. J. Clin. Endocrinol. Metab. 85, 4908-4911.

Tanaka, K., Minoura, H., Isobe, T., Yonaha, H., Kawato, H., Wang, D.F., Yoshida, T., Kojima, M., Kangawa, K., Toyoda, N., 2003. Ghrelin is involved in the decidualization of human endometrial stromal cells. J. Clin. Endocrinol. Metab. 88, 2335-2340.

Tanaka, M., Hayashida, Y., Nakao, N., Nakai, N., Nakashima, K., 2001. Testis-specific and developmentally induced expression of a ghrelin gene-derived transcript that encodes a novel polypeptide in the mouse. Biochim. Biophys. Acta. 1522, 62-65.

Tang-Christensen, M., Vrang, N., Ortmann, S., Bidlingmaier, M., Horvath, T.L., Tschop, M., 2004. Central administration of ghrelin and agouti-related protein (83-132) increases food intake and decreases spontaneous locomotor activity in rats. Endocrinology. 145, 4645-4652.

Tawadros, N., Salamonsen, L.A., Dimitradis E., Chen C, 2007. Facilitation of decidualization by locally produced ghrelin in the human endometrium. Mol. Hum. Reprod. 13, 483-489.

Tena-Sempere, M., Barreiro, M.L., 2002a. Leptin in male reproduction: the testis paradigm. 
Mol. Cell. Endocrinol. 188, 9-13.

Tena-Sempere, M., Barreiro, M.L., González, L.C., Gaytán, F., Zhang, F.P., Caminos, J.E., Pinilla, L., Casanueva, F.F., Diéguez, C., Aguilar, E., 2002b. Novel expression and functional role of ghrelin in rat testis. Endocrinology. 143, 717-725.

Tena-Sempere, M., 2008. Ghrelin and reproduction: ghrelin as novel regulator of the gonadotropic axis. Vitam. Horm. 77, 285-300.

Theander-Carrillo, C., Wiedmer, P., Cettour-Rose, P., Nogueiras, R., Perez- Tilve, D., Pfluger, P., Castaneda, T.R., Muzzin, P., Schurmann, A., Szanto, I., Tschop, M.H., Rohner-Jeanrenaud, F., 2006. Ghrelin action in the brain controls adipocyte metabolism. J. Clin. Invest. 116, 19831993.

Thompson, N.M., Gill, D.A., Davies, R., Loveridge, N., Houston, P.A., Robinson, I.C., Wells, T., 2004. Ghrelin and des-octanoyl ghrelin promote adipogenesis directly in vivo by a mechanism independent of the type 1a growth hormone secretagogue receptor. Endocrinology. 145, 234-242.

Toshinai, K., Mondal, M.S., Nakazato, M., Date, Y., Murakami, N., Kojima, M., Kangawa, K., Matsukura, S., 2001. Upregulation of ghrelin expression in the stomach upon fasting, insulininduced hypoglycemia, and leptin administration. Biochem. Biophys. Res. Commun. 281, $1220-1225$.

Tropea, A., Tiberi, F., Minici, F., Orlando, M., Gangale, M.F., Romani, F., Miceli, F., Catino, S., Mancuso, S., Sanguinetti, M., Lanzone, A., Apa, R., 2007. Ghrelin affects the release of luteolytic and luteotropic factors in human luteal cells. J. Clin. Endocrinol. Metab. 92, 3239-3245.

Tschop, M., Smiley, D.L., Heiman, M.L., 2000. Ghrelin induces adiposity in rodents. Nature. 407, 908-913.

Tschop, M., Weyer, C., Tataranni, P.A., Devanarayan, V., Ravussin, E., Heiman, M.L., 2001 a. Circulating ghrelin levels are decreased in human obesity. Diabetes. 50,707-709.

Tschop, M., Wawarta, R., Riepl, R.L., Friedrich, S., Bidlingmaier, M., Landgraf, R., Folwaczny, C., 2001b. Post-prandial decrease of circulating human ghrelin levels. J. Endocrinol. Invest. 24, RC19-RC21.

Ueberberg, B., Unger, N., Saeger, W., Mann, K., Petersenn, S., 2009. Expression of ghrelin and its receptor in human tissues. Horm. Metab. Res. 41, 814-821

Van Der Lely, A.J., Tschop, M., Heiman, M.L., Ghigo, E., 2004. Biological, physiological, pathophysiological, and pharmacological aspects of ghrelin. Endocr. Rev. 25, 426-457.

Viani, I., Vottero, A., Tassi, F., Cremonini, G., Sartori, C., Bernasconi, S., Ferrari, B., Ghizzoni, L., 2008. Ghrelin inhibits steroid biosynthesis by cultured granulosalutein cells. J. Clin. Endocrinol. 
Metab. 93, 1476-1481.

Vicennati, V., Genghini, S., De Iasio, R., Pasqui, F., Pagotto, U., Pasquali, R., 2007. Circulating obestatin levels and the ghrelin/obestatin ratio in obese women. Eur. J. Endocrinol. 157, 295301.

Vulliémoz, N.R., Xiao, E., Xia-Zhang, L., Germond, M., Rivier, J., Ferin, M., 2004. Decrease in luteinizing hormone pulse frequency during a five-hour peripheral ghrelin infusion in the ovariectomized rhesus monkey. J. Clin. Endocrinol. Metab. 89, 5718-5723.

Vulliemoz, N.R., Xiao, E., Xia-Zhang, L., Rivier, J., Ferin, M., 2008. Astressin B, a nonselective corticotropin-releasing hormone receptor antagonist, prevents the inhibitory effect of ghrelin on luteinizing hormone pulse frequency in the ovariectomized rhesus monkey. Endocrinology 149, 869-874.

Wasko, R., Komarowska, H., Warenik-Szymankiewicz, A. and Sowinski, J. 2004. Elevated ghrelin plasma levels in patients with polycystic ovary syndrome. Horm. Metab. Res. 36,170173.

Woods, S.C., D'Alessio, D.A., 2008. Central control of body weight and appetite. J. Clin. Endocrinol. Metab. 93 (11 Suppl 1), S37-50.

Wortley, K.E., Del Rincon, J.P., Murray, J.D., Garcia, K., Iida, K., Thorner, M.O., Sleeman, M.W., 2005. Absence of ghrelin protects against early-onset obesity. J. Clin. Invest. 115, 35733578.

Yan, W., Suominen, J., Toppari, J., 2000a. Stem cell factor protects germ cells from apoptosis in vitro. J. Cell. Sci. 113, 161-168.

Yan., W., Kero, J., Huhtaniemi, I., Toppari, J., 2000b. Stem cell factor functions as a survival factor for mature Leydig cells and a growth factor for precursor Leydig cells after ethylene dimethane sulfonate treatment: Implication of a role of the stem cell factor/c-kit system in Leydig cell development. Dev. Biol. 227,169-182.

Yoshimoto, A., Mori, K., Sugawara, A., Mukoyama, M., Yahata, K., Suganami, T., Takaya, K., Hosoda, H., Kojima, M., Kangawa, K., Nakao, K., 2002. Plasma ghrelin and desacyl ghrelin concentrations in renal failure. J. Am. Soc. Nephrol. 13, 2748-2752.

Zhang, W., Lei, Z., Su, J., Chen, S., 2008. Expression of ghrelin in the porcine hypothalamopituitary-ovary axis during the estrous cycle. Anim. Reprod. Sci. 109, 356-367.

Zhang, Y., Proenca, R., Maffei, M., Barone, M., Leopold, L., Friedman, J. M.,1994. Positional cloning of the mouse obese gene and its human homologue. Nature. 372, 425-432.

Zigman, J. M., Elmquist, J. K., 2003. From anorexia to obesity-The Yin and Yang of body 
weight control. Endocrinology. 144, 3749-3756.

Zwirska-Korczala, K., Sodowski, K., Konturek, S.J., Kuka, D., Kukla, M., Brzozowski, T., Cnota, W., Woźniak-Grygiel, E., Jaworek, J., Bułdak, R., Rybus-Kalinowska, B., Fryczowski, M. 2008. Postprandial response of ghrelin and PYY and indices of low-grade chronic inflammation in lean young women with polycystic ovary syndrome. J. Physiol. Pharmacol. 59 Suppl 2,161-178 


\section{Legend to figure 1}

Schematic representation of the interaction between energy balance, ghrelin and the hypothalamicpituitary-gonadal axis

The green arrow indicates moderate stimulatory effect and the red arrow indicates moderate inhibitory effect. Symbols: (+) marked stimulatory effect; (-) marked inhibitory effect 
